\title{
Survey of Beetles in Crop-Livestock-Forest Integration System in Southeast Brazil
}

ISSN: 2637-7659

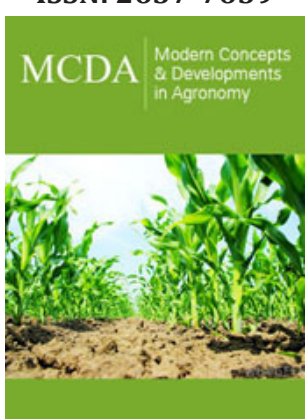

*Corresponding author: Igor SouzaGonçalves, Programa de Pós Graduação em Ecologia, Departamento de Biologia Geral, Universidade Federal de Viçosa, 36570900, Viçosa, Minas Gerais, Brasil

\section{Submission: 眥 May 05, 2020}

Published: 海眥 May 22, 2020

Volume 6 - Issue 3

How to cite this article: Igor SouzaGonçalves, Tatiana Rodrigues Carneiro, Paulo Afonso Viana. Survey of Beetles in Crop-Livestock-Forest Integration System in Southeast Brazil. Mod Concep Dev Agrono. 6(3). MCDA. 000637. 2020. DOI: 10.31031/MCDA.2020.06.000637

Copyright@ Igor Souza-Gonçalves, This article is distributed under the terms of the Creative Commons Attribution 4.0 International License, which permits unrestricted use and redistribution provided that the original author and source are credited.
Igor Souza-Gonçalves ${ }^{1,2 *}$, Tatiana Rodrigues Carneiro ${ }^{3}$ and Paulo Afonso Viana ${ }^{4}$

${ }^{1}$ Programa de Pós Graduação em Ecologia, Departamento de Biologia Geral, Universidade Federal de Viçosa, 36570-900, Viçosa, Minas Gerais, Brasil

${ }^{2}$ Laboratório de Sistemática e Biologia de Coleoptera, Departamento de Biologia Animal, Universidade Federal de Viçosa, 36570-900, Viçosa, Minas Gerais, Brasil

${ }^{3}$ Departamento de Soluções Educacionais, Faculdade Unimed, 30150-340, Belo Horizonte, Minas Gerais, Brasil

${ }^{4}$ Embrapa Milho e Sorgo, 35701-970, Sete Lagoas, Minas Gerais, Brasil

\begin{abstract}
The aim of this study was to determine the main families of beetles occurring in an integrated crop-livestock-forest system, evaluating the influence of abiotic factors (average temperature and rainfall) in their distribution in Prudente de Morais region, State of Minas Gerais, Brazil. The survey was carried out in the experimental farm EPAMIG Centro-Oeste. The sampling was conducted in five areas of the system. In each area were distributed nine pitfall traps which were weekly replaced. The sampling was made in the summer (02/03 to 03/02/2012) and in the winter (08/03 to 08/31/2012). The beetles were separated and identified at the family level, being the most representative ones identified to the tribe/genus. In the summer sampling Scarabaeidae (54.7\%), Carabidae (16.3\%) and Tenebrionidae (9.3\%), were the most representative families while in the winter sampling Tenebrionidae (67.1\%), Carabidae (14.6\%) and Staphylinidae (14.6\%) were the most representative ones.
\end{abstract}

Keywords: Agricultural Systems; Coleoptera; Occurrence

\section{Introduction}

The beetles (Insecta: Coleoptera) during their evolution have occupied most terrestrial environments, except for the oceans, and present the most varied feeding habits $[1,2]$. The success of these insects from their adaptability to diverse environments is believed to be due particularly to the morphological characters of the group, as the presence of elytra protecting the wings and the body. However, the most consistent among the hypotheses is related to the opening of the abdominal spiracles, in a space between the elytra and the abdomen, avoiding direct contact with the outside. Thus, the loss of body water is low [3]. In studies about the biodiversity of these insects, the planning of conservation and the management of natural resources, there is an important factor to consider it pertains to the variation in species richness on a landscape scale. Thus, the surveys of fauna in a certain region can provide information about the richness of these species [4]. Modifications of spatial composition of species are narrowly linked to environmental aspects generated by the variation of habitat. In Minas Gerais the natural landscapes are presented as a form of mosaic, created by human activity or by natural factors such as edaphic conditions.

The fauna of the soil fulfill an important role in the ecological process; therefore, studies about the composition and structure of these communities are primordial to understand how they work [5]. Several issues about biodiversity have been raised in the last decades; one of them is the role that monoculture exotic forests play in maintaining principally of the native fauna of insects. Some studies have shown that beetles are sensible to structural and floristic variations in small spatial scale [6]. In agricultural systems, the existence of these insects is also present providing relevant information about trophic relationships among the organisms in environments under the management of the soil and cattle [7]. For example, in crop-livestock-forest integration systems (iCLF), which constitutes a system with the 
objective of increase the utilization of biological cycles of plants and animals, in order to decrease the environmental impact and seeking to sustainability [8]. The use of this technique contributes to the reduction of pests and diseases, as well as to increase the biological activity of the soil. Each part of the system influences the diversity of insects because of some factors like shading, availability of food, temperature, humidity of soil [8].

There are several benefits of these systems integration involving the following sectors [9]:

A. Agronomic through maintaining and recovering of productive characteristics of the soil;

B. Economic through diversity of supply, obtaining higher yields at lower cost and higher quality;

C. Ecological through reducing the use of pesticides due to the consequent reduction of pest cultivated species, beyond reducing erosion;

D. Social for a more equal distribution of income, bigger generation of direct or indirect employments and the fixation of man in field [9].

Many studies have been conducted to obtain data about diversity, abundance and richness of beetles in different habitat $[7,10,11]$. However, the researches referents to this group of insects in this kind of system are still incipient [7]. In this study, the aim was to classify the main families of beetles present in a crop-livestockforest integration system and to evaluate the influence of abiotic factors (average temperature and rainfall) in their distribution, in Prudente de Morais/MG region.

\section{Material and Methods}

The survey of beetles' fauna was held in a system of croplivestock-forest integration (iCLF) implanted in experimental farm EPAMIG Centro-Oeste, Prudente de Morais, MG (1927'15 " S and $44^{\circ} 09^{\prime} 11^{\prime \prime} \mathrm{W}$, at $732 \mathrm{~m}$ ASL). The sampling was in the period of February $3^{\text {rd }} 2012$ to March $2^{\text {nd }} 2012$, and in the period of August $3^{\text {rd }}$ to August $31^{\text {st }}$ of the same year. The soil of the area is classified as clayey red-yellow latosol. Samplings were carried out in four (72x75m) individual plots of:

A. The forage Brachiaria decumbens cv Brasilisk in an intermediate state of recuperation;

B. The same forage in initial state of recuperation at full sun;

C. This forage with clone of eucalyptus GG100 (Eucalyptus grandisx Eucalyptus urophylla);

D. Only the clone of this eucalyptus.

Nine pitfall traps in each area were randomly distributed with a minimum distance of 10 meters. The traps consist in a plastic recipient buried at ground level, using a neutral detergent to keep the insects in it [12]. The pitfall traps were made of PET bottles by cutting the base of the two-liter bottle with $12 \mathrm{~cm}$ tall. Traps contained a solution of water and detergent in a proportion of
$700 \mathrm{ml}$ and 10 drops, respectively to break the superficial tension of the water. Samplings were realized in four weeks in summer and winter. The trapped beetles were collected at each Friday morning and the traps replaced. Aiming to preserve the material inside the trap, exposure to weather conditions and approaching vertebrates, acrylic protections were made with $20 \times 15 \times 0.2 \mathrm{~cm}$. The protections were set at $15 \mathrm{~cm}$ long wooden stakes and embedded in ground and keeping a distance of five centimeters between the protection and the trap.

The collected material was screened in the Laboratório de Entomologia/Resistência de Plantas e Manejo de Pragas of Embrapa Milho e Sorgo. The insects were kept in glasses containing 70\% alcohol to the classification being identified according to the trap number and the area in which they were captured. The beetles were mounted on entomological boxes and processed to identification initially of the families, using the taxonomic key of Triplehorn and Johnson [13] in Centro Universitário de Sete Lagoas (UNIFEMM). After this initial screening, the most representative specimens were identified at level tribe/genus, using the taxonomic key Vazde-Mello et al. [14] and by comparison with specimens from the collection of Laboratório de Sistemática e Biologia de Coleoptera of the Universidade Federal de Viçosa (MG). Meteorological data (average temperature and rainfall) were collected during the course of the whole work. It was used based on the main climatological station of Embrapa Milho e Sorgo, Sete Lagoas, MG, located about four kilometers from the experimental area. The number of beetles per trap at sampling times was subjected to analysis of variance and the average number compared by Tukey's test at $5 \%$ probability.

\section{Results and Discussion}

The average summer temperature varied between $22.4{ }^{\circ} \mathrm{C}$ and $23.4{ }^{\circ} \mathrm{C}$, with an average rainfall of $289.4 \mathrm{~mm}$; while in winter the average temperature recorded was between $19.7^{\circ} \mathrm{C}$ and 18.9 ${ }^{\circ} \mathrm{C}$ with an average rainfall of $5.0 \mathrm{~mm}$ (Figure 1). Beetles collected in the summer totaled 86 specimens, distributed in 13 families (Figure 2), being Scarabaeidae (54.7\%), Carabidae (16.3\%) and Tenebrionidae $(9.3 \%)$ the most representative families (Figure $3)$. In the winter were collected 82 beetles, grouped in six families (Figure 2), stood out Tenebrionidae (67.1\%), Carabidae (14.6\%) e Staphylinidae (14.6\%) (Figure 4). The data demonstrated that there was difference in the abundance of insects sampled at the times and in different areas by the Tukey's test $(\mathrm{P} \leq 0.05)$. In the period of summer, the area of forage (Brachiaria) in intermediate state of recuperation presented higher average number of insects, followed by the area of eucalyptus clone intercropping with the forage; but there was no significant difference between the area of eucalyptus and the area of forage in initial state of recovery at full sun. Already in the winter time, the forage area in the intermediate state of recovery remained still presented the highest abundance of insects, followed by the same forage area in initial state of full sun recovery, but there was no difference between the eucalyptus areas and eucalyptus associated with forage (Table 1). The four areas used in sampling, presented distinct distribution in relation to diversity and abundance, considering the two collection periods. 
The difference observed in the temperature and precipitation in both stations involved in the development of this present work proved to be representative, especially in the diversity of specimens collected, since these abiotic factors directly influence the diversity and distribution of these insects in the environment. The likely explanation is due to the higher viability of food resources that act in their population growth $[15,16]$; allowing a higher abundance in summer, where these factors were more likely.

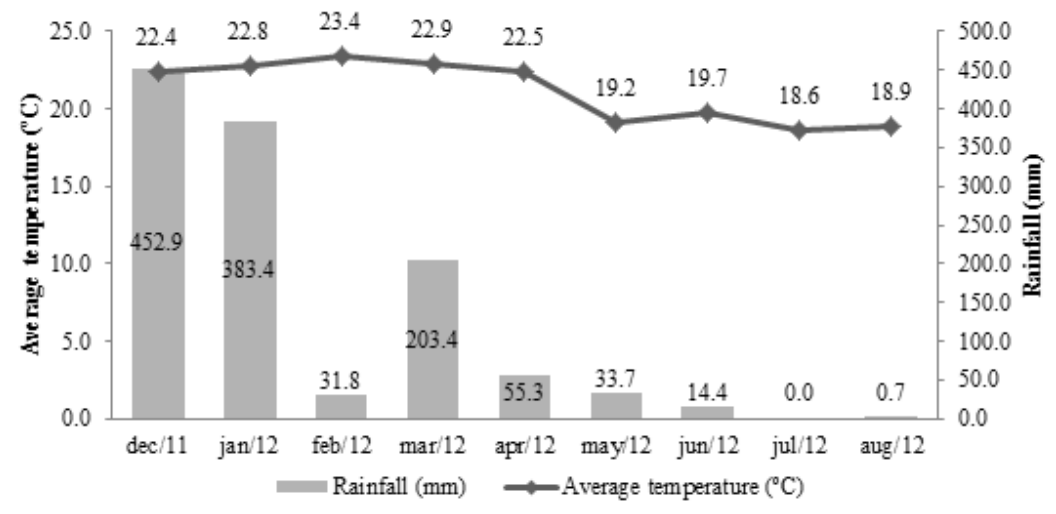

Figure 1: Temperature $\left({ }^{\circ} \mathrm{C}\right)$ and rainfall $(\mathrm{mm})$ from december 2011 to august 2012, Prudente de Morais region / MG.

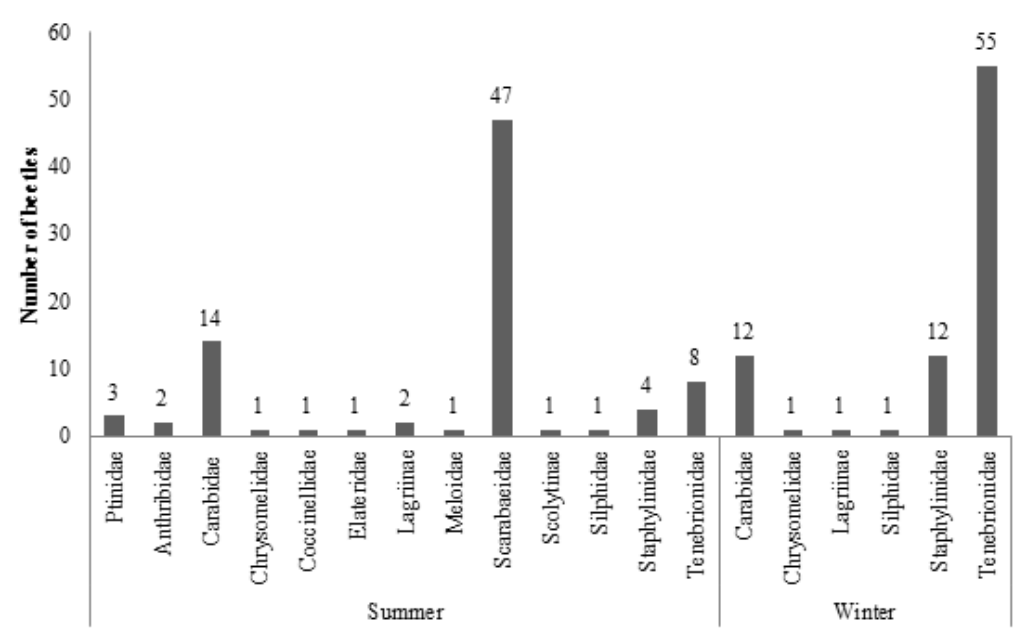

Figure 2: Abundance of the beetles' families by seasonal period (summer and winter) in a crop-livestock-forest integration system (iCLF), Prudente de Morais, MG, Brazil.

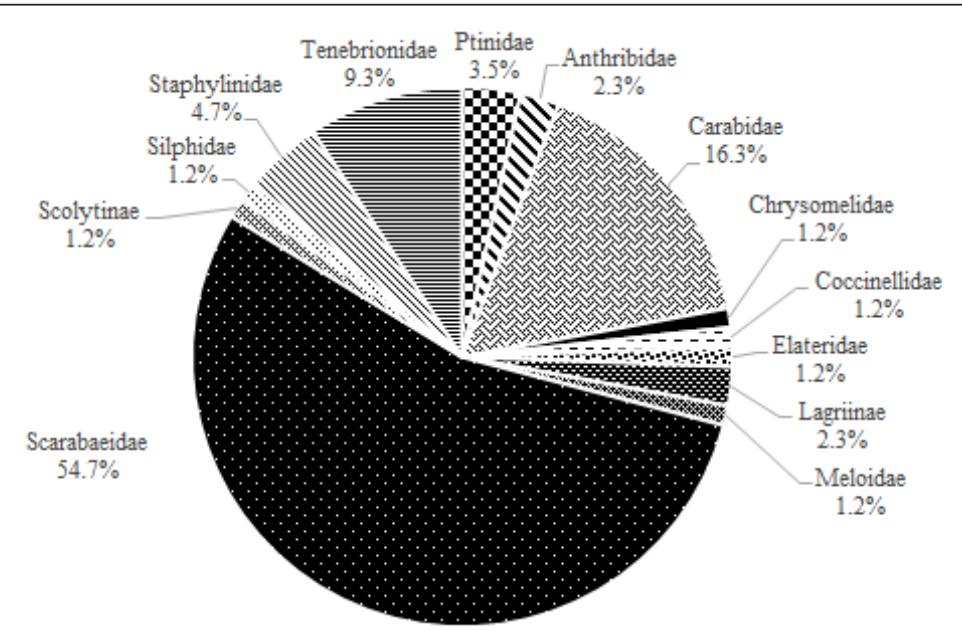

Figure 3: Percentage of beetles colleted in a crop-livestock-forest integration system (iCLFS), Prudente de Morais, MG, Brazil in summer. 


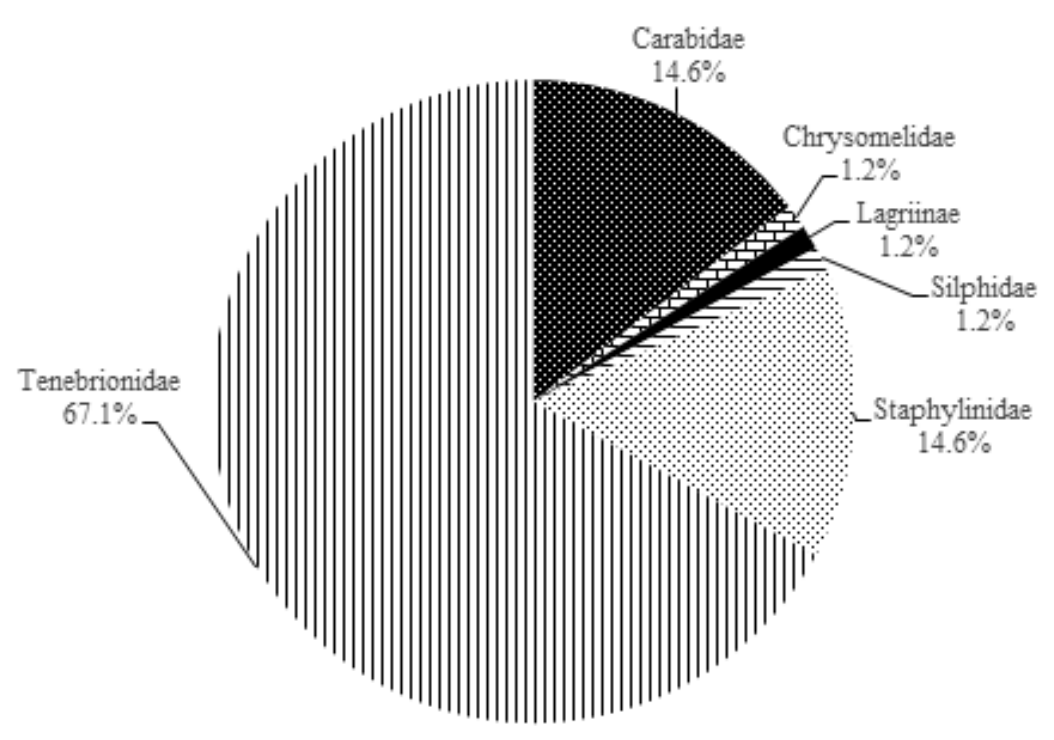

Figure 4: Percentage of beetles collected in a crop-livestock-forest integration system (iCLFS), Prudente de Morais, MG, Brazil in winter.

Table 1: Average number of beetles per trap in the seasons of sampling.

\begin{tabular}{|c|c|c|}
\hline Season & Treatments & Quantity of beetles* \\
\hline \multirow{4}{*}{ Summer } & Eucalyptus+Brachiaria & 5 a1 a2 \\
\hline & Brachiaria & $9 \mathrm{a} 2$ \\
\hline & Eucalyptus & $3 \mathrm{a} 1$ \\
\hline & Full sun & 3 a1 \\
\hline \multirow{4}{*}{ Winter } & Eucalyptus+Brachiaria & $3 \mathrm{~b} 1$ \\
\hline & Brachiaria & $16 \mathrm{~b} 2$ \\
\hline & Eucalyptus & $1 \mathrm{~b} 1$ \\
\hline & Full sun & 2 b1 b2 \\
\hline $\mathrm{CV}(\%)$ & \multicolumn{2}{|c|}{29,40} \\
\hline \multicolumn{3}{|c|}{ *Data transformed $\sqrt{\mathrm{x}}+1$} \\
\hline \multicolumn{3}{|c|}{ Same letters don't differing statistically at Tukey's test $(\mathrm{P} \leq 0,05)$} \\
\hline
\end{tabular}

From the data, it is clear that specimens of the Scarabaeidae were sampled only in the summer period in which rainfall and temperature were higher. What has been observed is due to the fact that these abiotic components cited above are the most important in the distribution of many insects in the environment $[17,18]$, resulting in a favorable way for the population development of these beetles. The prevalence of Scarabaeidae family also allows us to infer that the sampling area has a lower level of degradability, due to the fact that these beetles participate in important ecological services and be sensitive to environmental changes. Among the specimens of scarab beetles sampled was predominant the tribe Canthonini (Scarabaeidae: Scarabaeinae). Genera of others tribes were also sampled, Coprophaneus Olsoufieff (Scarabaeinae: Phanaeini), Holocephalus Hope (Scarabaeinae: Coprini), Dendropaemon Perty (Scarabaeinae: Phanaeini) e Anomiopus Westwood (Scarabaeinae:
Atheuchini). As can be seen all these specimens are members of Scarabaeinae subfamily, situated in detritivorous trophic group, saprophages trophic subgroup [19].

In relation at Tenebrionidae occurred the inverse of Scarabaeidae being sampled in a higher frequency in the winter, this likely happened due the adjustments of the individuals to the period where rainfall is low. Features evidenced by the fact that these insects can be found in desert or semi-desert regions around the world [20]. It is worth mentioning that there is need to carry out further work to assess the relationship between drought and the increase in population of Tenebrionidae. The most representative sample specimens of Tenebrionidae were the genera Epitragus Latreille (Pimeliinae: Epitragini) and Opatroides Brullé (Tenebrioninae: Opatrina), both with detritivorous eating 
habits [19], which can be observed due to occurring in most areas of Brachiaria where there is food availability of organic material in decomposition more evident. The carabids were sampled both in summer and winter, probably had their distribution related to the presence of herbaceous plants ranges, forests fragments and others habitats localizated near the used area, which served as primary shelter for these insects and others predators [21,22]. The representants of Carabidae are sensitive to antropic changes, considered indicators of the impact of crops and consequently bioindicators, being negatively affected by intensive agriculture [23]. From the data is possible to infer that areas such as the integration system study cause less impact on the environment, due the presence of these beetles during the entire sampling period. Relating the areas where the samples were realized, is possible to emphasize that there was less diversity of families as well as less insects in the area where there were only clones of eucalyptus (monoculture). The fact can be explicated by the negative effects caused by the implementation of monocultures due to a low diversity of crop products [23,24]. Some authors [25] from field survey data, said that most of the arthropod species occur in forest areas when compared to an area with eucalyptus. Possibly this is due to monoculture present discontinuous canopy and a poor litter [23]. It is also worth mentioning that because monoculture area to be shaded and have lower structural complexity, this influences the foraging surface and feeding and nesting ability of these insects. On the other hand, the other areas have a greater structural complexity such as vegetation diversity and area conservation.

\section{Conclusion}

The data showed that the average temperature and rainfall influence in the distribution of beetles within iCLF system in Prudente de Morais region / MG as well as in every area of it. The Scarabaeidae is predominant in summer, while Tenebrionidae stands out in winter. The Carabidae remains constant in both seasons.

\section{Acknowledgment}

The senior author thanks Dra ${ }^{\mathrm{a}}$. Maria Celuta Machado Viana for providing the area for work execution; Prof. Dr. Cristiano Lopes Andrade, Dr. Sérgio Zucateli Aloquio Junior and Dr. Ítalo Salvatore de Castro Pecci Maddalena of Laboratório de Sistemática e Biologia de Coleoptera of the Universidade Federal de Viçosa (UFV) for the identification of the most representative specimens to the tribe/ genus level; Daniela Castor Antunes for the revision of the language, and Embrapa Milho e Sorgo for the support and infrastructure in developing the project.

\section{References}

1. Lawrence JF, Britton EB (1991) Coleoptera. In: Commonwealth scientific and industrial research organization, the insects of Australia: a textbook for student and research workers, Melbourne University, Ithaca, New York, USA ( $2^{\text {nd }}$ edn), pp. 543-683.

2. Lima RL, Andreazze R, Andrade HHA, Pinheiro MPG (2010) Riqueza de famílias e hábitos alimentares em Coleoptera capturados na fazenda da EMPARN - Jiqui, Parnamirim/RN. EntomoBrasilis 3(1): 11-15.
3. Ianuzzi L, Maia ACD, Nobre CEB, Suzuky DK, Muniz FJA (2003) Padrões locais de diversidade de Coleoptera (Insecta) em vegetação da Caatinga. In: Leal IR, Tabarelli M, Silva JMC (Eds.), Ecologia e conservação da Caatinga, Editora Universitária da UEPE, Recife, Brazil, pp. 367-390.

4. Barbosa MGV, Fonseca CRV, Hammond PM, Stork NE (2002) Diversidade e similaridade entre habitats com base na fauna de Coleoptera de serrapilheira de uma floresta de terra firme da Amazônia Central. In: Costa C, Vanin SA, Lobo JM, Melic A (Eds.), Proyecto de Red Iberoamericana de Biogeografia y Entomologia Sistemática-PrIBES, Sociedad Entomológica Aragonesa, Zaragosa, Spain, pp. 69-83.

5. Teixeira CCCL, Hoffman M, Silva Filho G (2009) Comunidade de Coleoptera de solo em remanescente de Mata Atlântica no estado do Rio de Janeiro. Biota Neotropica 9(4): 91-95.

6. Marinoni RC, Ganho NG (2006) Beta differential diversity of Coleoptera (Insecta) in an anthropized landscape of the Bioma Araucaria. Rev Bras Entomol 50(1): 64-71.

7. Auad AM, Carvalho CA (2011) Faunistic analysis of beetles (Coleoptera) in a silvopastoral system. Ciência Florestal 21(1): 31-39.

8. Macedo MCM (2009) Crop and livestock integration: the state of the art and the near future. R Bras Zootec 38: 133-146.

9. Vilela L, Macedo MCM, Júnior GBM, Kluthcouski J (2003) Benefícios da Integração Lavoura Pecuária. In: Kluthcouski J, Stone LF, Aidar H (Org.), Integração Lavoura-Pecuária, Embrapa Arroz e Feijão, Santo Antônio de Goiás, Brazil, pp. 143-170.

10. Ganho NG, Marinoni RC (2005) A diversidade inventarial de Coleoptera (Insecta) em uma paisagem antropizada do Bioma Araucária. Rev Bras Entomol 49(4): 535-543.

11. Ganho NG, Marinoni RC (2006) Spatial variability of Coleoptera (Insecta) families between a Montane Ombrophilous Mixed Forest (Bioma Araucaria) and Pinus elliottii Engelmann plantation fragments, in the Parque Ecológico Vivat Floresta, Tijucas do Sul, Paraná, Brazil. Rev Bras Zool 23(4): 1159-1167.

12. Almeida LM, Ribeiro Costa CS, Marinoni L (1998) Manual de coleta, conservação, montagem e identificação de insetos, Holos: Ribeirão Preto, Brazil.

13. Triplehorn CA, Jonhson NF (2011) Estudo dos insetos (7a edn), Cengage Learning: São Paulo, Brazil.

14. Vaz de Mello FZ, Edmonds WD, Ocampo FC, Schoolmeesters P (2011) A multilingual key to the genera and subgenera of the subfamily Scarabaeinae of the New World (Coleoptera: Scarabaeidae). Zootaxa 2854(1): 1-73.

15. Endres AA, Hernandéz MIM, Duarte AJ (2005) Considerações sobre Coprophanaeus ensifer (Germar) (Coleoptera, Scarabaeidae) em um remanescente de Mata Atlântica no Estado da Paraíba, Brasil. Rev Bras Entomol 49(3): 427-429.

16. Rech T, Oliveira RC (2007) Biodiversidade e flutuação populacional de coleópteros em fragmento florestal em Cascavel, PR.

17. Browne FG (1961) The biology of malayan scolytidae and Platypodidae, Government Press: Malaya.

18. Wood SL (1982) The bark and ambrosia beetles of North and Central America (Coleoptera: Scolytidae) a taxonomic monograph. Great Basin Naturalistic Memoirs 6: 1-1356.

19. Marinoni RC, Ganho NG, Monné ML, Mermudes JRM (2001) Hábitos alimentares em Coleoptera (Insecta), Holos: São Paulo, Brazil.

20. Gahari H, Bunalsky M (2011) A study on darkling beetles (Coleoptera: Tenebrionidae) from south and southeastern Iran. Linz Biol Beitr 43(2): 1285-1290.

21. Pfiffner L, Luka H (2000) Overwintering of arthropods in soils of arable fields and adjacent semi-natural habitats. Agric Ecosyst Environ 78(3): 215-222. 
22. Martins ICF, Cividanes FJ, Augusto T, Gianni H (2009) Avaliação de área de refúgio para manipular populações de Carabidae (Coleoptera). Resumos do VI CBA e II CLAA. Rev Bras Agroecol 4(2): 1479-1483.

23. Wink C, Guedes JVC, Fagundes CK, Rovedder AP (2005) Soil borne insects as indicators of environmental quality. Rev Cien Agrovet 4(1): 60-71.
24. Vallejo LR, Fonseca CL, Gonçalves DRP (1987) Estudo comparativo da mesofauna do solo em áreas de Eucaliptus citriodora e mata secundária heterogênea. Rev Bras Biol 47(3): 363-370.

25. Ferreira RL, Marques MMGSM (1998) A fauna de artrópodes de serrapilheira de áreas de monocultura com Eucalyptus sp. e mata secundária heterogênea. An Soc Entomol Bras 27(3): 395-403.

For possible submissions Click below: 